Journal of Engineering and Fundamentals

Vol. 2(2), pp. 42-50, December, 2015

Available online at http://www.tjef.net

ISSN: 2149-0325

http://dx.doi.org/10.17530/jef.15.17.2.2

\title{
Optimization of cutting parameters and graphite rate in drilling of a hybrid aluminium matrix composites
}

\author{
M. Ay \\ Marmara University, Technical Education Faculty, Mechanical Education Department, \\ 34722, Istanbul, Turkey \\ Y. Altunpak \\ Abant Izzet Baysal University, Faculty of Engineering and Architecture, Mechanical
} Engineering, 14280, Bolu, Turkey

\begin{tabular}{ll}
\hline \hline Article history & Al/SiCp-Gr hybrid aluminum matrix composites are used for high \\
Received: & performance"ceramic" brake discs as it is able to withstand extreme \\
& temperatures. The addition of solid lubricant particles such as \\
Received in revised form: & graphite along with SiCp as hybrid reinforcements effectively \\
10.11 .2015 & improves the tribological properties of the composites. There is still \\
Accepted: & a need for the detailed, economic and systematic study of their \\
13.11 .2015 & machining characteristics in engineering applications of these \\
Key words: & composites. We report the influence of cutting parameters and \\
\hline hybrid composites, drilling, & effect of graphite rate on cutting force and surface roughness in \\
graphite, Taguchi method & drilling Al/20\%SiC/5\%Gr, Al/20\%SiC/7.5\%Gr and \\
& Al/20\%SiC/10\%Gr hybrid composites fabricated by vortex \\
& method. The drilling tests were conducted with diamond like \\
& carbon (DLC) coated cutting tools. Taguchi's L9 orthogonal array, \\
& S/N ratio and analysis of variance (ANOVA) were used for finding \\
& the optimal process parameters for cutting force and surface \\
& roughness, Ra. Linear regression model was developed for surface \\
& roughness and cutting force to check the model adequacy. \\
& Statistical analysis results show that the rate of graphite and feed \\
& was found to be significant parameters for surface roughness (Ra) \\
& and cutting force. Spindle speed has the insignificant effect on \\
& cutting force by the ANOVA The predicted values from the \\
& developed model and experimental values were found to be very \\
& similar in this study.
\end{tabular}




\section{Introduction}

Aluminium metal matrix composite $(\mathrm{Al}$ MMC) possess a number of mechanical and physical properties that make them attractive for automotive applications. Reinforcement of aluminium alloys with solid lubricants, hard ceramic particles, short fibres and whiskers effectively improves the mechanical, physical and tribological properties of the composites. Hybrid aluminium matrix composites are used for high performance "ceramic" brake discs since they are able to resist extreme temperatures [1] to [5].

Several studies are carried out on MMCs, drilling MMCs, researches on the improvement of the machinability of MMCs has been performed either to find new composites with better machinability or by testing the effect of the machining parameters on these new reinforced MMCs [3] to [6]. Manufacturers desire minimum cost, minimum surface roughness, and short production cycle. The tool life of HSS drill gets increased while machining graphite reinforced aluminium matrix composites compared to the base alloy. There is a reduction in energy required for drilling the composite compared to the base alloy since graphite being a solid lubricant reduces the friction at tool-work interface [7] and [8]. Basavarajappa et al. prepared two different metal matrix compositesAl2219/15SiCp and Al2219/15SiCp-3Gr by stir casting technique and performed drilling studies on them. They reported that ceramicgraphite reinforced composite has better machinability than those reinforced with silicon carbide particles only [6]. In the view of the growing engineering applications of these composites, there is still a need for the detailed and systematic study of their machining characteristics. The efficient and economic machining of these materials is required for the desired dimensions and surface finishing [9],
[10]. Surface finishing is an important procedure in evaluating the quality of products. Surface roughness is mostly used as an index to determine the surface finish in machining process [11].

Taguchi technique provides a simple, efficient and systematic approach to optimize the design for performance, quality and cost. The methodology is valuable when the design parameters are qualitative and discrete [6] to [8] and [10]. Engineering optimization of a process or a product should be carried out in a three-step approach, i.e. system design, parameter design, and tolerance design. Analysis of variance (ANOVA) are also employed to analyse the machining characteristics of these composites [9] and [10]. In recent years, the rapid growth of interest in the Taguchi method has led to numerous applications of the method in a worldwide range of industries and nations [12] and [13]. Literature, involves only few studies for Taguchi based optimization of machining parameters on a hybrid $\mathrm{Al} / \mathrm{SiC} / \mathrm{Gr}$ MMCs. Basavarajappa et al. studied on drilling of hybrid MMCs based on Taguchi techniques [6]. Rajmohan et al. used the Taguchi method for optimization of machining parameters in drilling A1356/SiC-mica composites [10].

This work aims to identify the cutting parameters and the effect of graphite rate on surface roughness and cutting force in drilling of $\mathrm{Al} / 20 \% \mathrm{SiC} / 5 \% \mathrm{Gr}, \mathrm{Al} / 20 \% \mathrm{SiC} / 7.5 \% \mathrm{Gr}$ and Al $/ 20 \% \mathrm{SiC} / 10 \% \mathrm{Gr}$ hybrid composites. To determine the optimum cutting conditions, Taguchi technique was used during study. Moreover, the effect of each parameter on the obtained results was determined by employing ANOVA. Finally, the relationship of the dependent parameters and independent parameters was modelled with regression analysis. 


\section{Materials and methods}

\subsection{Materials}

All composites were fabricated under similar conditions. Aluminium (LM2) was used as the matrix material. The composition of the Al-Si-Cu matrix alloy (\% by weight) was $\mathrm{Si}$ (12 max), $\mathrm{Cu}$ (0.7 to 0.9), $\mathrm{Fe}$ (0.7 max), $\mathrm{Mn}$ (0.25 max), $\mathrm{Mg}(0.02$ max), Zn (0.3 max), Ni (0.03 max), Ti (0.03 max), Pb (0.09 max), Al (balance). The $\mathrm{SiCp}$ particles and graphite particles average sizes were $53 \mu \mathrm{m}$ and $90 \mu \mathrm{m}$ respectively.

$\mathrm{Al} / 20 \% \mathrm{SiC} / 5 \% \mathrm{Gr}$ $\mathrm{Al} / 20 \% \mathrm{SiC} / 7.5 \% \mathrm{Gr}$ and $\mathrm{Al} / 20 \% \mathrm{SiC} / 10 \% \mathrm{Gr}$ hybrid composites were produced by vortex method and then squeezed with casting method which was discussed in detail in our previous study [1].

\subsection{Experimental procedure}

All drilling tests were performed on Johnford vertical CNC machining center. The machining samples were prepared in the form of $100 \mathrm{~mm} \times 10 \mathrm{~mm} \times 10 \mathrm{~mm}$ blocks for each material. The Diamond like carbon (DLC Drill regular NACHI DLCDR5.0 LIST 9520) coated cutting tools of $5 \mathrm{~mm}$ diameter was used. A fresh tool was used to drill each material (three holes) for all cutting conditions. The point angles were $118^{\circ}$. Coolant was not used in all of the drilling tests. The experiment were performed at different speeds of 3500, 4000 and $4500 \mathrm{rpm}$ and feed rates of 350, 400 and $450 \mathrm{~mm} / \mathrm{min}(0.1,0.13$ and $0.16 \mathrm{~mm} / \mathrm{rev})$ as given in Table 1 . The experimental conditions were shown in detail as in an earlier paper [1].

The obtained experimental results and the determined parameters were optimized with Taguchi method. Using regression model, researches were carried out calculating an equation between dependent parameters and independent parameters. The Taguchi method uses a special design of orthogonal arrays to study the entire parameter space with a few experiments only. The experimental results were then transformed into a signal-to-noise $(\mathrm{S} / \mathrm{N})$ ratio. Taguchi recommends the use of the $\mathrm{S} / \mathrm{N}$ ratio to measure the quality characteristics deviating from the desired values. Usually, there are three categories of quality characteristic in the analysis of the $\mathrm{S} / \mathrm{N}$ ratio [12] and [13].

Table 1. Experiment factors and their levels

\begin{tabular}{cccc}
\hline Parameters & $\begin{array}{c}\text { Spindle Speed } \\
(\mathrm{rpm})\end{array}$ & $\begin{array}{c}\text { Feed } \\
(\mathrm{mm} / \mathrm{rev})\end{array}$ & $\begin{array}{c}\text { (C) } \\
\text { Rate of } \\
\text { Graphite } \\
(\%)\end{array}$ \\
\hline Level I & 3500 & 0.1 & 5 \\
Level II & 4000 & 0.13 & 7.5 \\
Level III & 4500 & 0.16 & 10.0 \\
\hline
\end{tabular}

Experimental design was done using Taguchi method. Therefore, we were able to reach more comprehensive results with doing less experiment. In this sense, time and money have been used more efficiently [14] and [15]. The

$$
S / N(\eta)=-10 x \log \left(\frac{1}{n} \sum_{i=1}^{n} y_{i^{2}}\right)
$$
cutting force $(\mathrm{N})$ was calculated by considering smaller-the-better characteristics (in decibel) and given by 
Where $\mathrm{n}$ is the number of experiments done under experiment conditions and y represents the calculated characteristics (dependent variable).

\section{Result and discussion}

We discuss the influence of the cutting parameters and the effect of graphite on surface roughness (Ra) and cutting force $(\mathrm{N})$ on drilling of a hybrid $\mathrm{Al} / \mathrm{SiC} / \mathrm{Gr}$ MMCs with DLC coated drills in this section.

\subsection{Analysis of $S / N$ ratio and ANOVA for surface roughness and cutting force}

The S/N ratio for cutting force and surface roughness were calculated by considering smaller-the-better characteristics. The experimental results were analyzed using analysis of variance (ANOVA). Taguchi $\mathrm{L}_{9}$ experiment design, surface roughness, $\mathrm{S} / \mathrm{N}$ ratios of surface roughness and cutting force values were also shown in Table 2.

Figures 1 and 3 show the 3-dimensional response graph for surface roughness and cutting force with feed and different graphite rates in drilling of the composites. The graphs point out the increase of feed rate increases the surface roughness and cutting force, whereas the increase graphite rate increases surface roughness but reduces the cutting force in all conditions.

Table 2. Taguchi L9 experiment design, surface roughness and cutting force, $\mathrm{S} / \mathrm{N}$ ratios of surface roughness values

\begin{tabular}{cccccc}
\hline $\begin{array}{c}\text { Exp. } \\
\text { No. }\end{array}$ & Variables & $\begin{array}{c}\text { Surface } \\
\text { Roughness, } \\
\text { Ra }(\mu \mathrm{m})\end{array}$ & $\begin{array}{c}\text { S/N } \\
\text { Ratios } \\
\mathrm{Ra}(\mu \mathrm{m})\end{array}$ & $\begin{array}{c}\text { Cutting } \\
\text { Force }(\mathrm{N})\end{array}$ & $\begin{array}{c}\text { S/N } \\
\text { Ratios } \\
\text { Force }(\mathrm{N})\end{array}$ \\
\hline 1 & $\mathrm{~A}_{1} \mathrm{~B}_{1} \mathrm{C}_{1}$ & 0.511 & 5.83158 & 703.31 & -56.943 \\
2 & $\mathrm{~A}_{1} \mathrm{~B}_{2} \mathrm{C}_{2}$ & 0.746 & 2.54522 & 572.64 & -55.158 \\
3 & $\mathrm{~A}_{1} \mathrm{~B}_{3} \mathrm{C}_{3}$ & 1.014 & -0.1208 & 509.95 & -54.151 \\
4 & $\mathrm{~A}_{2} \mathrm{~B}_{1} \mathrm{C}_{2}$ & 0.507 & 5.89984 & 369.71 & -51.357 \\
5 & $\mathrm{~A}_{2} \mathrm{~B}_{2} \mathrm{C}_{3}$ & 0.741 & 2.60364 & 348.82 & -50.852 \\
6 & $\mathrm{~A}_{2} \mathrm{~B}_{3} \mathrm{C}_{1}$ & 0.597 & 4.48051 & 878.62 & -58.876 \\
7 & $\mathrm{~A}_{3} \mathrm{~B}_{1} \mathrm{C}_{3}$ & 0.595 & 4.50966 & 324 & -50.210 \\
8 & $\mathrm{~A}_{3} \mathrm{~B}_{2} \mathrm{C}_{1}$ & 0.429 & 7.35085 & 698.91 & -56.888 \\
9 & $\mathrm{~A}_{3} \mathrm{~B}_{3} \mathrm{C}_{2}$ & 0.685 & 3.28619 & 498.23 & -53.948 \\
\hline
\end{tabular}

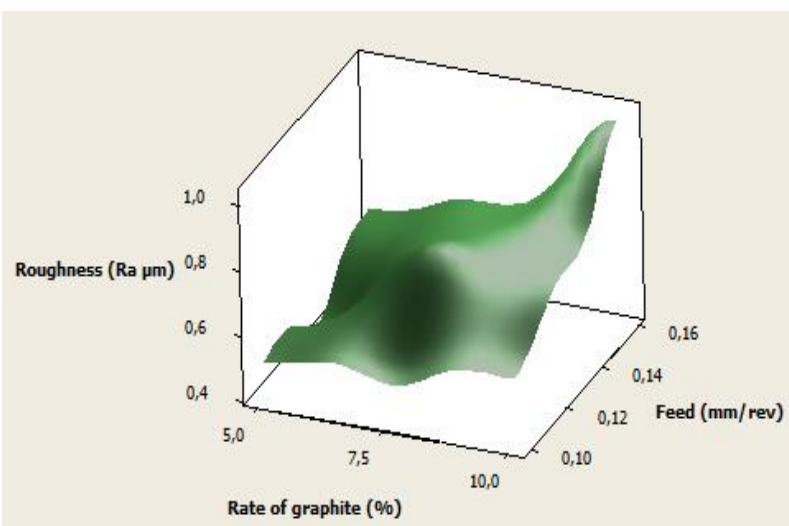

Figure 1. 3-D response graph for surface roughness ( $\mathrm{Ra}$ ) in drilling of the composites 


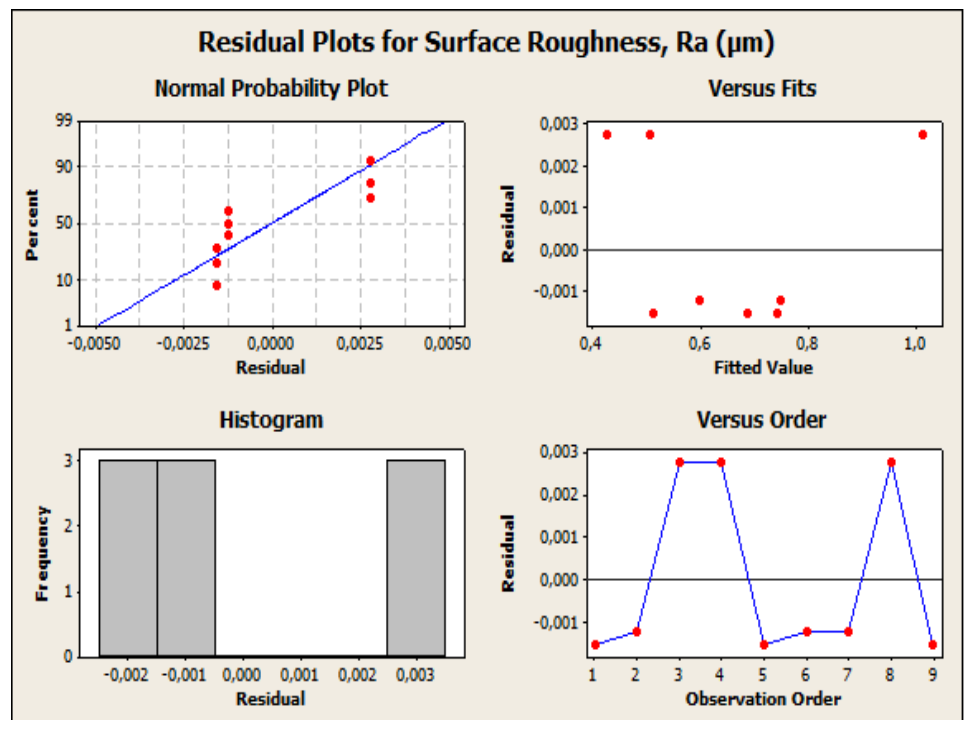

Figure 2. The ANOVA analysis for spindle speed, rate of graphite and feed rate on surface roughness

In drilling of the composites with cutting tools coated with DLC, nine experiments were carried out using three different factors at three different levels and different $\mathrm{Ra}$ values were obtained from each experiment. The influence of each factor in this answer will be determined by the analysis of variance (Figure 2 and 4 ).
Figures 1 and 3 display the normal probability plots for the surface roughness and the cutting force, respectively. Graphite content in the composites reduces the cutting force, but increases the surface roughness (Ra). Similar results were also obtained in our previous experimental study [1].

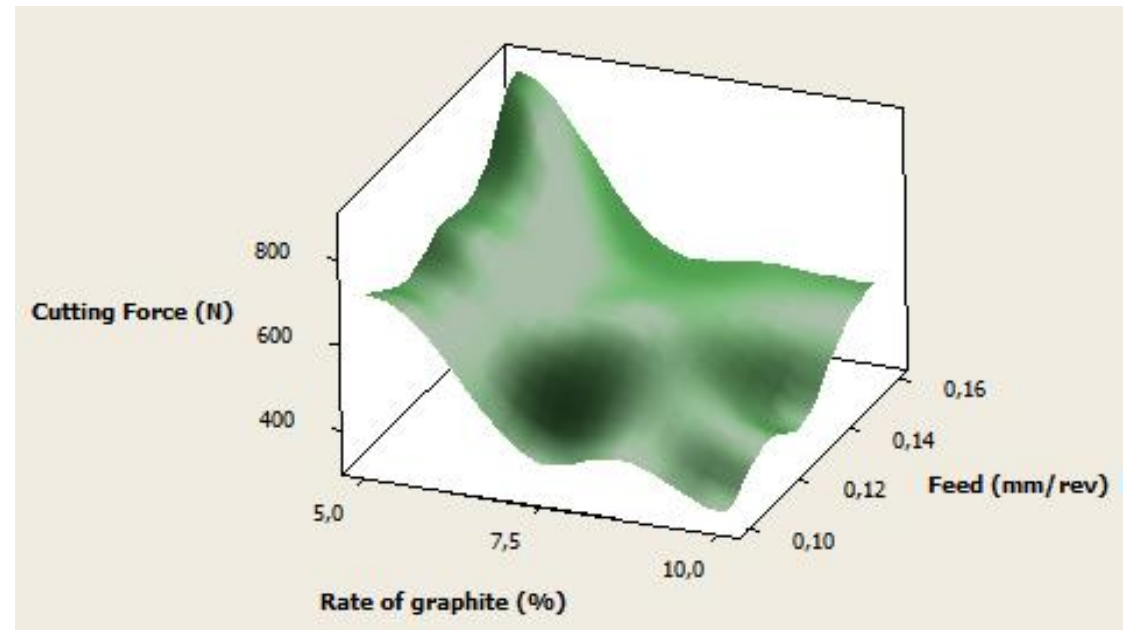

Figure 3. 3-D response graph for cutting force in drilling of the composites 


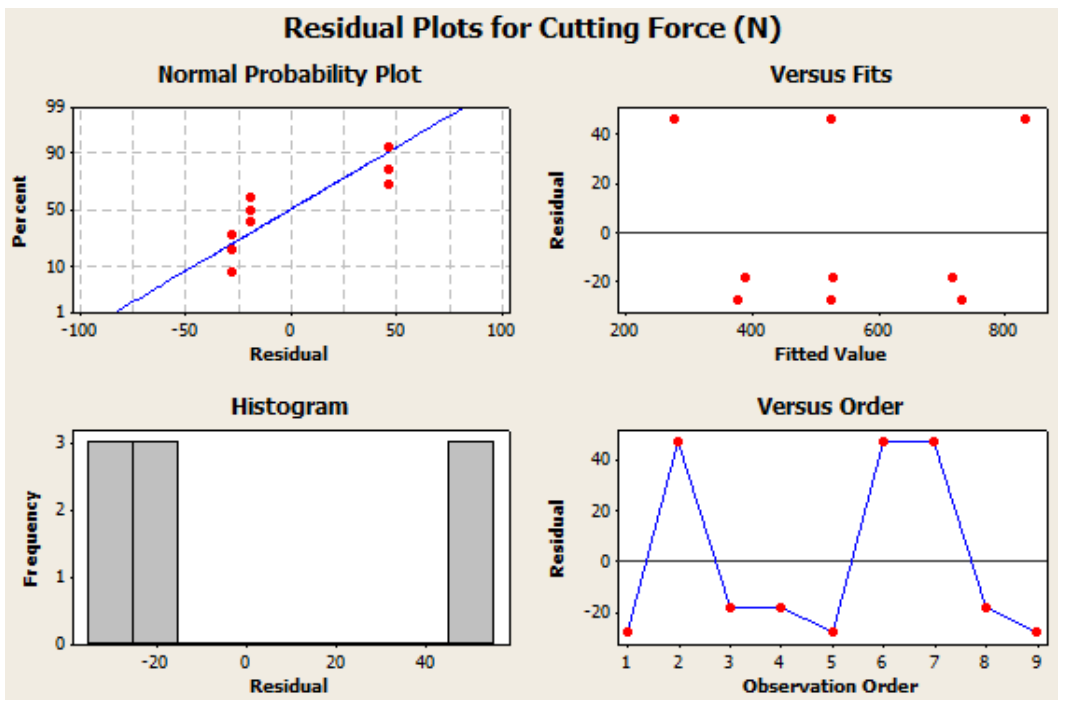

Figure 4. The ANOVA analysis for rate of graphite and feed rate on cutting force

Table 3 lists the numerical values of ANOVA results with the average values of surface roughness. Present results in Table 3 show that the rate of graphite and feed have significant effect on the surface roughness (Ra) with $44.87 \%$ and $31.79 \%$ respectively. However, spindle speed appears to have little effect on surface roughness.

Table 3. ANOVA results based on Ra values

\begin{tabular}{cccccc}
\hline Notations & $\begin{array}{c}\text { Degree } \\
\text { of } \\
\text { Freedom }\end{array}$ & $\begin{array}{c}\text { Sum of } \\
\text { Squares }\end{array}$ & Variables & F ratio & Percentage (\%) \\
\hline Spindle Speed & 2 & 0.05731 & 0.02866 & 1642.73 & 23.33 \\
Feed Rate & 2 & 0.07807 & 0.03904 & 2237.89 & 31.79 \\
Rate of graphite & 2 & 0.11017 & 0.05508 & 3157.69 & 44.87 \\
Fault (e) & 2 & 0.00004 & 0.00002 & & 0.01 \\
Total & 8 & 0.24559 & & & 100 \\
\hline
\end{tabular}

Table 4 summarizes the ANOVA results of the average values of cutting force. The rate of graphite with a proportion of $79.72 \%$ has the most significant effect on the cutting force as shown in Table 4. This may be due to the effect of graphite that helps the materials to shear easily [1] and [6]. However, feed rate and spindle speed appear to have very little effect on cutting force.

Table 4. ANOVA results based on cutting force values

\begin{tabular}{lcclcc}
\hline \multicolumn{1}{c}{ Notations } & $\begin{array}{c}\text { Degree of } \\
\text { Freedom }\end{array}$ & $\begin{array}{c}\text { Sum of } \\
\text { Squares }\end{array}$ & Variables & F ratio & Percentage $(\%)$ \\
\hline Spindle Speed & 2 & 12389 & 6195 & 1.24 & 4.55 \\
Feed & 2 & 40084 & 20042 & 4.01 & 14.73 \\
Rate of graphite & 2 & 219807 & 109903 & 21.97 & 79.72 \\
Fault (e) & 2 & 10007 & 5003 & & 0.01 \\
Total & 8 & 282287 & & & 100 \\
\hline
\end{tabular}




\subsection{Regression model for surface roughness and cutting force}

We developed a regression model for both surface roughness and cutting force. To formulate a predictive equation between the control factors used during chip removal (feed rate, spindle speed and rate of graphite) and the result (average surface roughness, $\mathrm{Ra}$ ) and to define this relationship, linear regression analysis was used. Figure 5 shows the, normal probability plots. The Ra equation formulated for this experimental study was represented below:

$$
\operatorname{Ra}(\mu \mathrm{m})=0.079-0.000187 \mathrm{~A}+0.00228 \mathrm{~B}+0.0542 \mathrm{C}=96.7 \%
$$

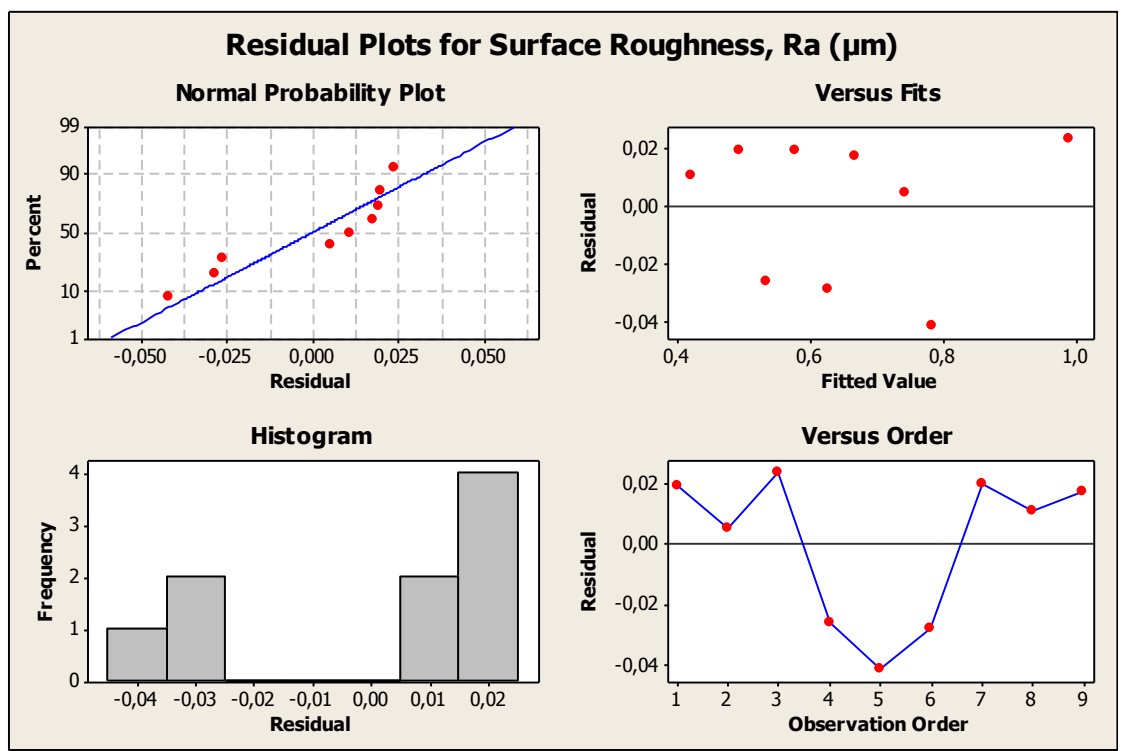

Figure 5. The regression analysis for rate of graphite and feed on surface roughness

To formulate a predictive equation between the control factors used during chip removal (feed rate, spindle speed and rate of graphite) and the result (average cutting force) and to define this relationship, linear regression analysis was used. Figure 6 again displays the normal probability plots. The cutting force $(\mathrm{N})$ equation formulated for this experimental study was in the form of:

Cutting Force $(\mathrm{N})=836-44.1 \mathrm{~A}+81.6 \mathrm{~B}-183 \mathrm{C}=89.5 \%$ 


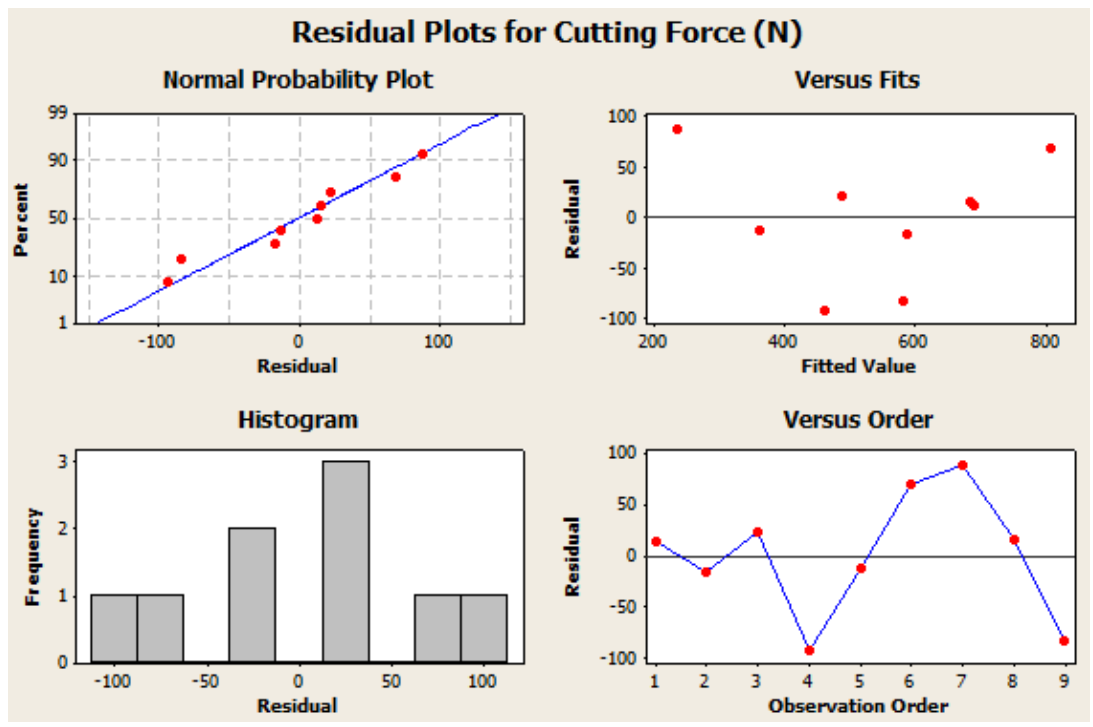

Figure 6. The regression analysis for rate of graphite and feed on cutting force

\section{Conclusions}

In summary, we surveyed the the drilling of $\mathrm{Al} / 20 \% \mathrm{SiC} / 5 \% \mathrm{Gr}$, $\mathrm{Al} / 20 \% \mathrm{SiC} / 7.5 \% \mathrm{Gr}$ and $\mathrm{Al} / 20 \% \mathrm{SiC} / 10 \% \mathrm{Gr}$ using diamond like carbon (DLC) coated cutting tools at different cutting parameters. Taguchi's L9 orthogonal array, $\mathrm{S} / \mathrm{N}$ ratio and ANOVA were used for finding the optimal process parameters for cutting force and surface roughness, $\mathrm{Ra}$. Linear regression model was developed for surface roughness and cutting force to check the model adequacy. The following conclusions can be drawn from the analysis of results.

(i) Based on the $\mathrm{S} / \mathrm{N}$ ratios obtained from experiments, the optimal cutting parameters were A3B2C1 for surface roughness i.e. spindle speed at $4500 \mathrm{rpm}$, feed at $0.13 \mathrm{~mm} / \mathrm{min}$ and graphite rate is $5 \%$ for surface roughness $(\mathrm{Ra})$ and A3B1C3 for cutting force i.e. spindle speed at $4500 \mathrm{rpm}$, feed at $0.1 \mathrm{~mm} / \mathrm{rev}$ and graphite rate is $10 \%$ for cutting force.

(ii) The rate of graphite and feed was found to be significant parameters for surface roughness ( $\mathrm{Ra}$ ) with $44.87 \%$ and $31.79 \%$ followed by spindle speed (cutting speed) $23.33 \%$ by the ANOVA.

(iii) The rate of graphite was the most significant effect on the cutting force with a proportion of $79.72 \%$ followed by feed rate $14.73 \%$. Spindle speed has the insignificant effect on cutting force by the ANOVA.

(iv) The predicted values from the developed model and experimental values are found to be very similar to each other justifying the significant of the model.

\section{References}

[1] Altunpak Y, Ay M, and Aslan S.

Drilling of a hybrid $\mathrm{Al} / \mathrm{SiC} / \mathrm{Gr}$ metal matrix composites. The International Journal of Advanced Manufacturing Technology 2012; 60(5): 513-517. DOI: 10.1007/s00170-0113644-4.

[2] Prasad S.V, and Asthana R. Aluminum Metal-Matrix Composites for Automotive Applications. Tribological Considerations, Tribology Letters 2004; 17(3): 445-453. DOI: 10.1023/B:TRIL.0000044492.91991.f3.

[3] Hayajneh MT, Hassan A.M, and Mayyas AT. Artificial neural network 
modeling of the drilling process of selflubricated aluminum/alumina/graphite hybrid composites synthesized by powder metallurgy technique. Journal of Alloys and Compounds 2009; 478: 559-565. DOI:10.1016/j.jallcom.2008.11.155.

[4] Basavarajappa S, Chandramohan G, Mahadevan A. Thangavelu M. Subramanian, $\mathrm{R}$ and Gopalakrishnan P. Influence of sliding speed on the dry sliding wear behaviour and the subsurface deformation on hybrid metal matrix composite. Wear 2007; 262: 10071012. http://dx.doi.org/10.1016/j.wear.2006.10.016. [5] Gultekin D, Uysal M, Aslan S, Alaf M, Guler MO and Akbulut $\mathrm{H}$. The effects of applied load on the coefficient of friction in $\mathrm{Cu}-\mathrm{MMC}$ brake pad/Al-SiCp MMC brake disc system. Wear 2010; 270:73-82 http://dx.doi.org/10.1016/j.wear.2010.09.001.

[6] Basavarajappa S, Chandramohan G and Davim J. Some studies on drilling of hybrid metal matrix composites based on Taguchi techniques Journal of Materials Processing Technology 2008; 196(1-3): 332-338. http://dx.doi.org/10.1016/j.jmatprotec.2007.0 $\underline{5.043}$

[7] Asiltürk I. Application of Artificial Intelligent to Predict Surface Roughness. Experimental Techniques; 2014; 38: 54-60. DOI: 10.1111/j.1747-1567.2012.00827.x

[8] Raj A.M, Das SL, and Palanikumarr K. Influence of drill geometry on surface roughness in drilling of $\mathrm{Al} / \mathrm{SiC} / \mathrm{Gr}$ hybrid metal matrix composite. Indian Journal of Science and Technology 2013; 6(7): 50025007. DOI: $10.17485 / \mathrm{ijst} / 2013 / \mathrm{v} 6 \mathrm{i} 7 / 34356$ [9] El-Gallab M, and Sklad M. Machining of $\mathrm{Al} / \mathrm{SiC}$ particulate metal matrix composites Part II. Workpiece Surf Integr. Journal of Materials Processing Technology 1998; 83: 277-285. http://dx.doi.org/10.1016/S0924$\underline{0136(98) 00054-5}$
[10] Rajmohan, T, Palanıkumar, K, and Kathırvel, M, Optimization of machining parameters in drilling hybrid aluminium metal matrix composites Transactions of Nonferrous Metals Society of China 2012; 22: 1286-1297. http://dx.doi.org/10.1016/S10036326(11)61317-4.

[11] Ali, A.M, Adesta, E.Y.T, Augusman, D, Badari, S.N.M, and Al-Hazza, M.H.F.

Development of Surface Roughness

Prediction Model for High Speed End Milling of Hardened Tool Steel. Asian Journal of Scientific Research; 2011; 4(3): 255-263. DOI: 10.3923/ajsr.2011.255.263.

[12] Tosun G. Statistical analysis of process parameters in drilling of $\mathrm{Al} / \mathrm{SiC}_{\mathrm{P}}$ metal matrix composite. The International Journal of Advanced Manufacturing Technology; 2011; 55: 477-485. DOI 10.1007/s00170-0103103-7.

[13] Yang, W.H, and Tarng, Y.S. Design optimization of cutting parameters for turning operations based on the Taguchi method. The Journal of Materials Processing Technology; 1998; 84: 122-129.

http://dx.doi.org/10.1016/S09240136(98)00079-X.

[14] Chung-Chen, T, and Honk, $\mathrm{H}$. Comparison of the tool life of tungsten carbides coated by multi-layer TiCN and TiAlCN for end mills using the Taguchi method. The Journal of Materials Processing Technology; 2002; 123: 1-4. http://dx.doi.org/10.1016/S09240136(01)01152-9

[15] Kivak T. Optimization of surface roughness and flank wear using the Taguchi method in milling of Hadfield steel with PVD and CVD coated inserts. Measurement 2014; 50: $19-28$. http://dx.doi.org/10.1016/j.measurement.2013 .12 .017

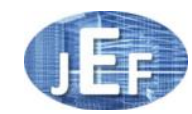

